Хлопяк С.В., к. е. н., дои.

Київський національний торговельно-економічний університет, м. Київ, Україна Google Scholar https://scholar.google.com.ua/citations?user=Tj1pDkMAAAAJ\&hl=uk

\title{
ТЕХНОЛОГІЧНІ ОСНОВИ РОЗВИТКУ КАРАВАНІНГУ ЯК ФОРМИ СПЕЦІАЛІЗОВАНОГО ТУРИЗМУ
}

Одним з визначальних трендів розвитку світового туризму на сучасному етапі постає глобальний пошук та впровадження нових спеціалізованих форм організації туристичних подорожей, що на противагу масовим формам відповідають критеріям економічності, індивідуальності, можливості під час однісї поїздки отримати якомога більше вражень.

На тлі прискорення темпу життя, зростання кількості автомобілів у приватному користуванні, підвищення рівня урбанізації та розширення мережі якісних автодоріг все більшої популярності серед туристів набуває караванінг - подорожі людей до країн або місцевостей, відмінних від місць їх постійного проживання, в яких основним засобом пересування та проживання виступають автобудинки та автопричепи. Цілі караванінгу та способи використання будинків на колесах досить різноманітні - це і тривалі автоподорожі, що передбачають огляд історико-культурних та природних пам'яток, $\mathrm{i}$ відпочинок «вихідного дня», і стоянка на місці у кемпінгу протягом сезону, і заняття спортом. Ключовою перевагою цієї форми туризму, що може бути зручною та захопливою, як для сімей з дітьми, так і для груп молодих людей та пенсіонерів, є можливість протягом відпустки чи канікул змінити декілька місць відпочинку, не вирішуючи при цьому питань, пов'язаних $з$ орендою нерухомості. Поняттям-синонімом караванінгу $є$ ервінг (RVing або RV), від англійського recreational vehicle - транспортний засіб для відпочинку та розваг.

У теперішній час під впливом факторів економічної стабільності та розвитку дорожньої інфраструктури караванінг отримав широке розповсюдження насамперед у Європі, Америці, Японії. Він спричинив зародження цілої індустрії, що охоплює виробників автобу- 
динків, прокатні компанії, сервісні станції, кемпінги, спеціалізовані туристичні підприємства.

У 2016 році доходи кемпінгів, RV та автопарків у США становили майже 5 млрд доларів, Великій Британії - 3 млрд, Франції 2,6 млрд, Німеччині - 520 млн, Іспанії - 510 млн, Аргентині - 230 млн дол. Прогнози оптимістичні: очікується, що у 2022 році доходи RV-індустрії у Сполученому Королівстві сягнуть 4,6 млрд доларів, Франції - 3,3 млрд, Німеччині та Іспанії - 750 млн. У сфері автокемпінгів США сьогодні задіяно понад 45 тисяч осіб, У Франції - майже 11 тисяч.

Стрімко зростають і показники роздрібних продажів автомобілів для відпочинку. Так, у Канаді в 2017 році вони досягли позначки у 6 млрд дол. США, в Японії, яка лише починає виходити на цей ринок 380 млн дол., що на 200 млн більше, ніж у 2011 році. Кількість приватних автофургонів японців цього ж року збільшилася до 106 тисяч одиниць, що удвічі перевищує показник 2005 року.

Для тимчасового мобільного проживання у караванінгу використовуються кемпінги - території на відкритому повітрі, обладнані відповідно до потреб автотуристів. Якщо у готелях гостям надаються номери, то у кемпінгах - майданчики під тимчасове розміщення автомобілів з наметами, житлових причепів та автобудинків. В умовах зростаючої конкуренції новітні технології дозволили кемпінгам адаптуватися до потреб ринку і запропонувати комплексний туристський продукт, що поєднує у собі комфорт та безпеку проживання у вигляді комбінації різних видів послуг: харчування, організації нічлігу та відпочинку, облаштування душових кабін та туалетів, утилізації відходів, індивідуального підключення до енерго- та водопостачання тощо. Рівень сервісу у кемпінгу може бути достатньо високим (з пральнею, сауною, басейном, тенісними кортами) або обмеженим (інколи без гарячої води), але у будь-якому разі таким, що забезпечує санітарний мінімум.

Ціни на стоянки у кемпінгах залежать від їх категорії та регіону розташування. Приміром, кемпінги поблизу Венеції, попри не найвищу якість, традиційно є одними 3 найдорожчих. Порівняно 3 ними аналогічні заклади у Австрії виявляються значно дешевшими.

Караванінг в Україні натомість дотепер залишається відносно непоширеним явищем. I цьому $є$ широкий спектр причин - від обмежених економічних можливостей населення i низької якості шляхів сполучення до відсутності у вітчизняних фахівців практичного досвіду організації кемпінгів та успішного просування їх на світовому і внутрішньому туристських ринках. 
На початковому етапі розв'язання комплексу цих проблем, насамперед, повинно передбачати:

- утворення національної асоціації кемперів як саморегульованої організації в галузі автотуризму і караванінгу;

- розроблення норм, технічних та організаційних стандартів для українських кемпінгів відповідно до міжнародних вимог;

- проведення досліджень в галузі караванінгу: збір та аналіз статистичних даних туристських ринків, порівняння стану кемпінгтуризму в Україні та закордоном. Корисною може бути організація та участь у міжнародних, національних та регіональних автотуристських виставках, форумах, фестивалях.

Україна має у своєму розпорядженні величезні природні ресурси і території, придатні для прокладання цікавих маршрутів для автотуристів та організації місць їх тимчасових зупинок, обладнаних за європейськими стандартами. Очевидно, що розвиток вітчизняного караванінгу та кемпінг-туризму вже сьогодні може мати позитивний вплив на динаміку іноземного та внутрішнього туристичних потоків в нашій країні. 